\title{
Efektivitas Kuersetin Fraksinasi Daun Teh Hijau Sebagai Antioksidan dan Antiagregasi Platelet Terhadap Stabilitas Bahan Kontrol dan Darah Simpan
}

\author{
Eem Hayati, Adang Durachim, Betty Nurhayati, Aditya Juliastuti \\ Analis Kesehatan Politeknik Kesehatan Bandung
}

\begin{abstract}
Abstrak
Berdasarkan Permenkes Nomor 46 Tahun 2015 tentang Akreditasi Puskesmas dokumen yang harus terpenuhi sesuai kriteria persyaratan akreditasi yaitu terdapatnya SOP tentang Pemantapan Mutu Internal (PMI) dan Pemantapan Mutu Eksternal (PME). Bahan kontrol komersial sangat baik digunakan untuk pelaksanaan PMI karena sangat stabil sampai masa expiry date nya, namun secara ekonomis relatif mahal. Bahan kontrol yang banyak digunakan diantaranya bahan kontrol darah lengkap komersial untuk pemeriksaan hematologi. Bahan kontrol darah lengkap alternatif sangat diperlukan untuk dapat digunakan secara rutin agar pengadaannya lebih terjangkau baik oleh laboratorium puskesmas atau laboratorium institusi Pendidikan. Tujuan penelitian adalah menganalisis pembuatan bahan kontrol buatan dari Packed Red Cell sebagai alternatif penggunaan bahan kontrol komersial. Bahan tambahan yang digunakan dalam penelitian adalah kuersetin yang diperoleh dari hasil fraksinasi daun teh hijau. Berdasarkan penelitian sebelumnya telah diketahui kuersetin dapat berfungsi sebagai antioksidan dan anti agregasi platelet. Jenis penelitian adalah eksperimen laboratorium. Hasil penelitian setelah diuji dengan General Linier Model (GLM) dapat disimpulkan bahan kontrol yang ditambah dengan kuersetin, jumlah eritrosit stabil selama 20 hari,dan lekosit stabil 15 hari. Tetapi untuk trombosit disimpan selama 5 hari sudah tidak stabil, sedangkan bahan kontrol komersil disimpan selama 15 hari sudah terjadi penurunan jumlah sel.
\end{abstract}

Kata Kunci : Bahan kontrol buatan, Bahan kontrol dan Kuersetin.

\section{Effectiveness of Quercetin Fractionation Green Tea Leaves as Antioxidants and Anti-Aggregation of Platelets on Stability Control Material and Stored Blood}

\begin{abstract}
Based on Permenkes No. 46 of 2015 Public Health Center Accreditation documents must according to accreditation requirements criteria namely SOPs on Internal and External Quality Assurance (IQA and EQA). Commercial control materials are very good IQA's implementation because very stable until they expiry date, but economically relatively expensive. Control materials are widely used include commercial whole blood material for hematology examination. Alternative whole blood control materials are needed to used routinely and procurement is more affordable, either by puskesmas or educational institution laboratories. The objective research is to analyze artificial control materials from Packed Red Cells as an alternative commercial control materials. Additional material that will be used in this research is quercetin which obtained from the fractionation of green tea leaves. Based on previous research it's known that quercetin as an antioxidant and antiplatelet aggregation. This research method was laboratory experiment. Results of study statistically tested with General Linier Model (GLM) can be concluded that control material added with quercetin, the erythrocytes number stable for 20 days, leukocytes are stable for 15 days, and platelets stored for 5 days are unstable, while the commercial control material stored for 15 days has decreased the number of cells.
\end{abstract}

Keywords: : Artificial control material, Control material and Quercetin.

Korespondensi: Eem Hayati, S.Pd., M.Kes, Analis Kesehatan, Politeknik Kesehatan Kemenkes Bandung, Jl. Babakan Loa No. 10A Cimahi Utara, e-mail eem.hayati@yahoo.com 


\section{Pendahuluan}

Sistem pelayanan kesehatan di Indonesia digambarkan dalam piramid, yaitu pelayanan primer, sekunder, dan tersier. Layanan kesehatan di tingkat primer merupakan tulang punggung pelayanan kesehatan di Indonesia terutama dalam era Jaminan Kesehatan Nasional (JKN). Saat ini, terdapat sebanyak 9599 Puskesmas tersebar di seluruh Nusantara dan para tenaga kesehatan (Nakes) di dalamnya memiliki peran penting dalam tercapainya citacita pembangunan kesehatan. Bahwa sebenarnya yang paling besar peranannya adalah yang berada di posisi di bawah, yaitu pelayanan primer. Keberhasilan pelayanan kesehatan melalui Puskesmas memberikan kontribusi yang cukup besar dalam pembangunan kesehatan (Kemenkes, 2012).

Terdapat sejumlah prinsip pelayanan kesehatan primer, yaitu salah satunya upaya pemerataan dalam pelayanan kesehatan, menekankan pada upaya preventif, penggunaan teknologi tepat guna, peningkatan peran masyarakat, dan peningkatan kerjasama lintas sektor. Dalam upaya mendukung pelayanan kesehatan, di puskesmas terdapat berbagai kegiatan pelayanan di antaranya yaitu pelayanan laboratorium. Laboratorium puskesmas melaksanakan pengukuran, penetapan, dan pengujian terhadap bahan yang berasal dari manusia untuk penentuan jenis penyakit, penyebaran penyakit, kondisi kesehatan, atau faktor yang dapat berpengaruh pada kesehatan perorangan dan masyarakat di wilayah kerja puskesmas. Untuk dapat melaksanakan fungsi pelayanan laboratorium di puskesmas dibutuhkan sumber daya manusia yang mencukupi baik jumlah maupun mutunya (Kemenkes, 2012 dan Kemenkes, 2013).

Di samping sumber daya manusia yang berkualitas, dalam Penyelenggaraan Laboratorium Klinik yang Baik (GLP) disebutkan Setiap Laboratorium Klinik harus diselenggarakan secara baik dengan memenuhi kriteria organisasi, ruang dan fasilitas, peralatan, bahan, spesimen, metode pemeriksaan, mutu, keamanan, pencatatan dan pelaporan. Untuk dapat memberikan perbaikan secara tepat terhadap kesalahan yang terjadi, suatu laboratorium harus dapat mengidentifikasi sumber kesalahannya pada setiap tahapan pemeriksaan laboratorium, baik pada tahap pra analitik, analitik, ataupun pasca analitik (Sacher dan Mc Pherson, 2004) Mutu pemeriksaan di laboratorium dipengaruhi oleh penetapan mutu internal dengan penggunaan bahan kontrol
(Tuna dan Widyaningsih, 2017).

Bahan kontrol adalah bahan yang digunakan untuk memantau ketepatan suatu pemeriksaan di laboratorium, atau untuk mengawasi kualitas hasil pemeriksaan seharihari. Bahan kontrol komersial sangat baik digunakan untuk pelaksanaan PMI karena sangat stabil sampai masa expiry date nya, namun secara ekonomis relatif mahal sehingga untuk penggunaan bahan kontrol komersial secara rutin di laboratorium terutama laboratorium puskesmas atau laboratorium institusi pendidikan kurang terjangkau dan cukup memberatkan. (Dean, 2005)

Sehubungan penggunaan bahan kontrol sangat berperan penting dalam menjaga kualitas hasil pemeriksaan laboratorium secara rutin, maka perlu dikembangkan bahan kontrol alternatif untuk keperluan rutin yang untuk tahap awal minimal dapat diaplikasikan di laboratorium pendidikan (Siregar dkk, 2018).

Dalam rangka stabilitas bahan kontrol darah simpan diperlukan bahan tambahan agar dapat disimpan dalam waktu yang relatif lama. Bahan tambahan yang akan digunakan dalam penelitian adalah kuersetin yang diperoleh dari hasil fraksinasi daun teh hijau. Berdasarkan penelitian sebelumnya telah diketahui kuersetin dapat berfungsi sebagai antioksidan dan anti agregasi platelet. Dengan demikian berpotensi mencegah terjadinya agregasi trombosit pada darah simpan pada suhu refrigerator $\left(2-8^{\circ} \mathrm{C}\right)$ (Dewi dkk, 2017).

Tujuan dilakukan penelitian ini adalah untuk menganalisis stabilitas bahan control buatan untuk dapat digunakan secara rutin agar pengadaannya lebih terjangkau baik oleh laboratorium puskesmas atau laboratorium institusi Pendidikan.

\section{Metode}

Jenis penelitian ini adalah eksperimen laboratorium. Waktu penelitian dilakukan pada bulan Agustus sampai November 2019 di laboratorium Hematologi Jurusan Teknologi Laboratorium Medik Poltekkes Kemenkes Bandung. Bahan yang digunakan dalam penelitian ini adalah fraksi kuersetin dan darah donor yang difungsikan sebagai bahan kontrol hematologi. Prosedur kerja penelitian ini yaitu: bahan kontrol buatan ditambah kuersetin dengan berbagai konsentrasi $(53,6 \mathrm{mg} / 100 \mathrm{~mL}$ darah., $26,8 \mathrm{mg} / 100 \mathrm{~mL}$ darah dan 13,4 $\mathrm{mg} / 100 \mathrm{~mL}$ darah), dan bahan kontrol tanpa kuersetin. Lalu bahan kontrol disimpan selama 20 hari pada temperatur $2-8^{\circ} \mathrm{C}$, dan setiap 5 hari 
dilakukan pemeriksaan parameter darah lengkap (hemoglobin, hematocrit, eritrosit, lekosit, trombosit, nilai $\mathrm{MCV}, \mathrm{MCH}, \mathrm{MCHC}$ ). Jadi perlakuan dalam penelitian ini adalah 20 dengan pengulangan sebanyak 4 kali.

Sebagai unit eksperimen dalam penelitian ini adalah darah donor dari PMI Kota Bandung. Bahan kontrol dibuat dalam sejumlah vial sesuai dengan kebutuhan. Untuk uji homogenitas diambil secara acak 5 vial bahan kontrol untuk dilakukan pengujian. Untuk Uji stabilitas bahan kontrol diperiksa selama 20 hari. Pemeriksaan dilakukan pada hari pertama, pemeriksaan selanjutnya dilakukan dengan jarak 5 hari sampai hari ke 20 (KAN, 2004).

Semua data uji stabilitas disajikan pada grafik levey Jenning's untuk dinilai distribusi datanya dan dibandingkan dengan bahan kontrol komersial. Uji Kinerja bahan kontrol dilakukan dengan cara menilai distribusi data bahan kontrol dengan interpretasi Westgard multirule, dan dibandingkan dengan bahan kontrol komersial.

\section{Hasil}

1. Jumlah Eritrosit

Berdasarkan hasil pemeriksaan jumlah eritrosit terjadi penurunan rata-rata jumlah eritrosit sampai penyimpanan selama 20 hari pada masing-masing perlakuan.

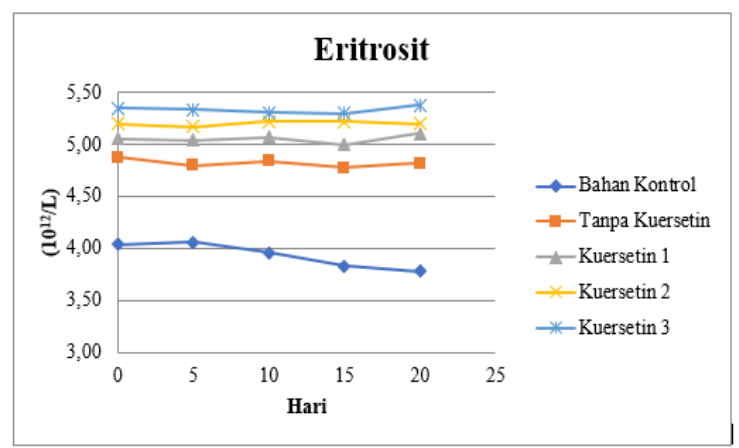

Gambar 1. Hasil Pemeriksaan Jumlah Eritrosit

\section{Kadar Hemoglobin}

Hasil pemeriksaan menunjukkan terjadi penurunan rata-rata kadar hemoglobin sampai penyimpanan selama 20 hari pada suhu lemari es.

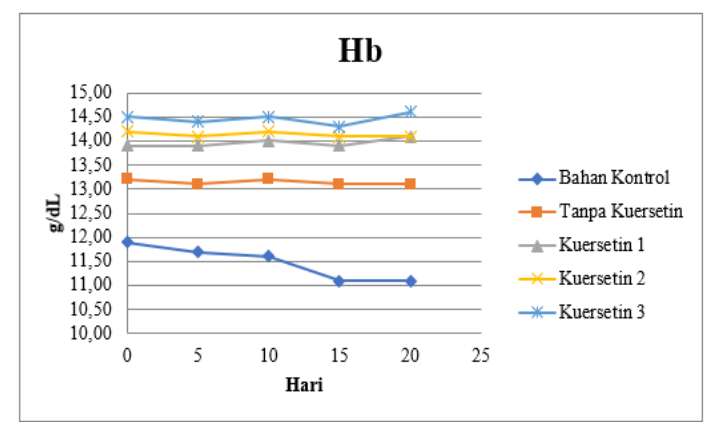

Gambar 2. Hasil Pemeriksaan Kadar Hemoglobin

Kadar hemoglobin pada bahan kontrol sudah mulai menurun pada hari ke 15 ini sesuai dengan lama simpan bahan kontrol karena hemoglobin ada dalam eritrosit, data hampir sama dengan eritrosit.

\section{Indeks Eritrosit}

Hasil pemeriksaan nilai MCV, MCH dan MCHC menunjukkan nilai yang relatif stabil sampai penyimpanan selama 20 hari pada suhu lemari es.

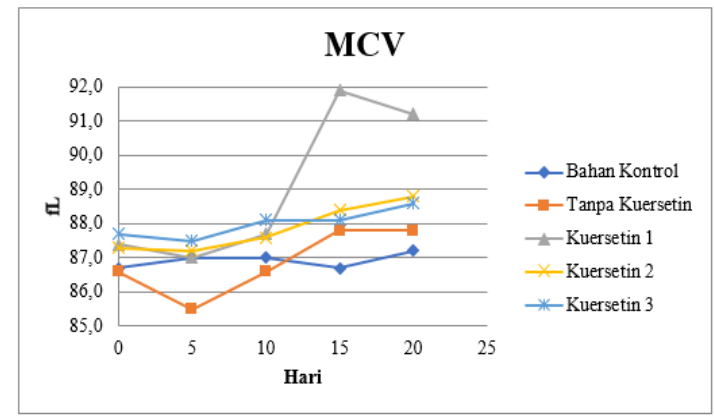

Gambar 3. Hasil Pemeriksaan MCV

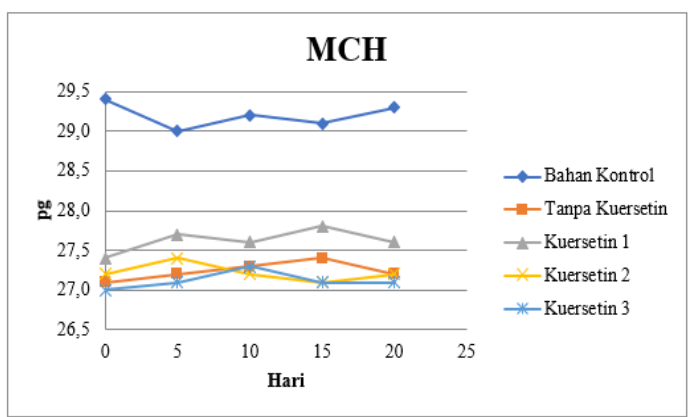

Gambar 4. Hasil Pemeriksaan MCH

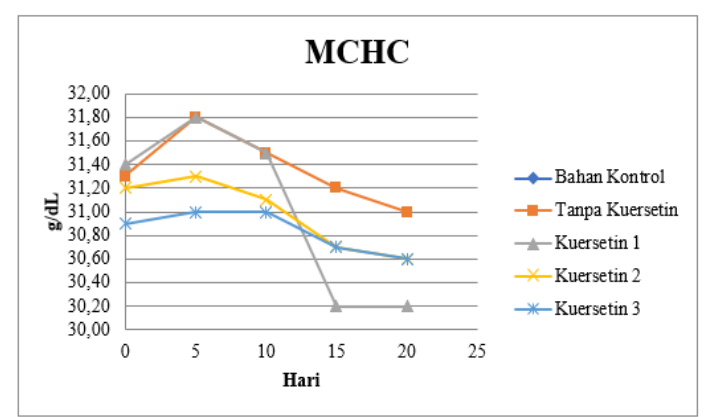

Gambar 5. Hasil Pemeriksaan MCHC 
Pada grafik pemeriksaan $\mathrm{MCH}, \mathrm{MCV}$ dan MCHC memberikan gambaran yang hampir sama dengan eritrosit. Penyimpanan eritrosit berpengaruh terhadap kualitas sel sehingga mempengaruhi hasil $\mathrm{MCH}, \mathrm{MCV}$ dan MCHC.

\section{Leukosit}

Terjadi penurunan rata-rata jumlah lekosit sampai penyimpanan selama 20 hari pada suhu lemari es.

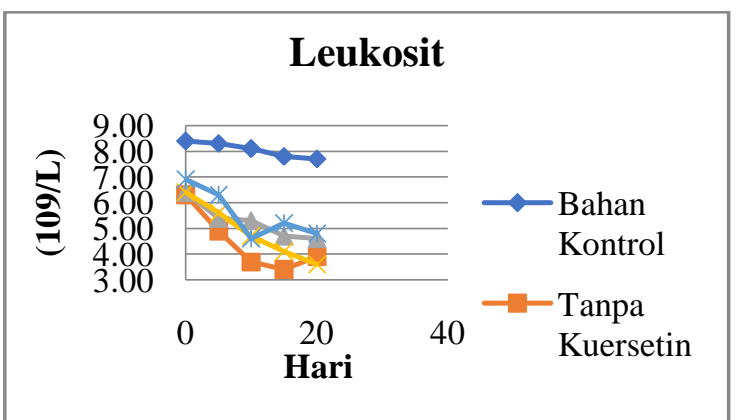

Gambar 6. Hasil Pemeriksaan Leukosit

Grafik di atas memperlihatkan jumlah leukosit pada bahan kontrol stabil sampai 20 hari ini disebabkan karena bahan kontrol menggunakan sel sintesis untuk leukosit sehingga stabil lama, berbeda dengan yang berasal dari darah simpan tidak stabil sampai hari ke 20 karena masa hidup leukosit di dalam tubuh sekitar 10 hari. Bila dibandingkan dengan yang ditambah kuersetin masa hidup leukosit lebih lama dibandingkan dengan yang tanpa kuersetin.

\section{Trombosit}

Terjadi penurunan rata-rata jumlah trombosit dalam darah yang tidak ditambahkan kuersetin sampai penyimpanan selama 20 hari pada suhu lemari es.

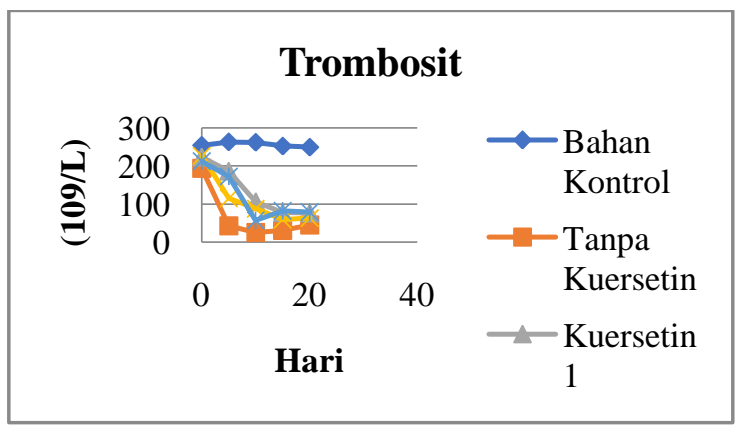

Gambar 7. Hasil Pemeriksaan Trombosit

Uji stabilitan kuersetin terhadap darah simpan dilakukan dengan cara penambahan kuersetin berbagai konsentrasi terhadap darah simpan dan dihitung menggunakan Uji GLM secara statistik.

1. Jumlah Eritrosit pada darah simpaan tanpa kuersetin stabil hingga penyimpanan darah hari ke-10. Bahan kontrol untuk pemeriksaan jumlah erirosit stabil hingga penyimpanan hari ke-10 (Hari 15 sudah tidak stabil secara statistik)

2. Kadar $\mathrm{Hb}$ pada darah bahan kontrol stabil hingga penyimpanan hari ke-5 (Hari 10 sudah tidak stabil secara statistik), sedangkan kadar $\mathrm{Hb}$ darah yang ditambah kuersetin stabil sampi penyimpanan selama 20 hari.

3. Indeks $\mathrm{MCV}$ pada darah simpan tanpa kuersetin, dengan kuersetin 1 dan 3 tidak stabil secara statistik pada hari ke-5. Sedangkan darah simpan dengan kuersetin 2 tidak stabil secara statistik pada hari ke10. Bahan Kontrol stabil hingga 20 hari pengujian.

4. Indeks $\mathrm{MCH}$ pada darah simpan tanpa kuersetin stabil hingga hari 15 (Tidak stabil secara statistik pada hari 20). Darah Bahan kontrol, Darah simpan dengan Variasi kuersetin stabil hingga hari 20.

5. Indeks MCHC pada darah simpan dengan kuersetin $1(52 \mu \mathrm{L} / \mathrm{mL}$ darah) stabil hingga hari 10 (Tidak stabil secara statistik pada hari 15). Darah Bahan kontrol, Darah simpan dengan Variasi kuersetin 2 dan 3 stabil hingga hari 20.

6. Jumlah Leukosit pada darah simpan dengan kuersetin $2(26 \mu \mathrm{L} / \mathrm{mL}$ darah) tidak stabil secara statistik pada hari 5 .

Jumlah Leukosit pada bahan kontrol, darah simpan tanpa kuersetin dan dengan kuersetin $3(13 \mu \mathrm{L} / \mathrm{mL}$ darah) tidak stabil secara statistik pada hari 10 Darah simpan dengan kuersetin $1(52 \mu \mathrm{L} / \mathrm{mL}$ darah) stabil hingga hari 15 secara statistik.

7. Jumlah Trombosit pada darah simpan dengan dan tanpa kuersetin tidak stabil secara statistik pada hari 5.

8. Bahan kontrol stabil secara statistik hingga hari 20 untuk parameter trombosit

\section{Pembahasan}

Berdasarkan Gambar 1. jumlah Eritrosit pada darah simpan tanpa kuersetin stabil hingga penyimpanan darah hari ke-10. Bahan kontrol untuk pemeriksaan jumlah erirosit stabil hingga penyimpanan hari ke-10 (Hari 15 sudah tidak stabil secara statistik), hal ini sesuai dengan kriteria pada darah kontrol yang pada umumnya 
stabil selama 2 minggu, sedangkan darah yang ditambah kuersetin masih stabil sampai penyimpanan selama 20 hari, hal ini membuktikan bahwa kuersetin berfungsi sebagai antioksidan sehingga dapat menjaga kerusakan dinding sel eritrosit dan eritrosit tidak lisis. Demikian juga kadar $\mathrm{Hb}$ pada Gambar 2. menunjukkan darah bahan kontrol stabil hingga penyimpanan hari ke-5 (Hari 10 sudah tidak stabil secara statistik), sedangkan kadar $\mathrm{Hb}$ darah yang dicampur dengan kuersetin stabil selama penyimpanan selama 20 hari. Hemoglobin berada dalam eritrosit sehingga apabila eritrosit utuh maka $\mathrm{Hb}$ berada dalam eritrosit. Hal ini sama untuk nilai MCV, $\mathrm{MCH}$ dan $\mathrm{MCHC}$, karena berhubungan dengan eritrosit.

Jumlah Leukosit pada darah simpan dengan kuersetin $2(26 \mu \mathrm{L} / \mathrm{mL}$ darah) tidak stabil secara statistik pada hari 5 sedangkan jumlah Leukosit pada bahan kontrol, darah simpan tanpa kuersetin dan dengan kuersetin 3 $(13 \mu \mathrm{L} / \mathrm{mL}$ darah) tidak stabil secara statistik pada hari 10 dan darah simpan dengan kuersetin $1(52 \mu \mathrm{L} / \mathrm{mL}$ darah) stabil hingga hari 15 secara statistik, dapat disimpulkan bahwa makin tinggi kuersetin makin lama masa stabil sel leukosit, ini membuktikan bahwa kuersetin dengan konsentrasi tertentu dapat befungsi sebagai antioksidan terhadap sel leukosit di luar tubuh. Masa hidup leukosit di dalam tubuh selama 10 hari, sehingga dapat dibuktikan bahwa dengan penambahan kuersetin masa hidup leukosit diluar tubuh hampir menyerupai keadaan di dalam tubuh.

Kuersetin sebagai anti oksidan, mekanisme sebagai anti oksidan dapat dibedakan berdasarkan cara kerja, yaitu anti oksidan enzimatik dan anti oksidan non enzimatik. Anti oksidan enzimatik terdiri dari glutathione peroxidase dan katalase yang berfungsi melindungi sel dari tekanan oksidatif dan yang non enzimatik terdiri dari glutathione banyak terdapat di dalam sitoplasma sel.

Jumlah Trombosit pada darah simpan yang ditambah dengan kuersetin maupun tanpa penambahan kuersetin tidak stabil secara statistik pada hari 5 dan bahan kontrol stabil secara statistik hingga hari 20 untuk parameter trombosit, hal ini disebabkan karena pada darah konrol trombosit yang ada merupakan sintesis karena trombosit tidak bisa bertahan lama berada di luar tubuh. Pada darah simpan hanya stabil selama 5 hari, disebabkan karena masa hidup trombosit hanya 7 hari di dalam tubuh, jadi di luar tubuh masa hidup rombosit lebih singkat dan kemungkinan konsentrasi kuersetin terlalu rendah untuk dapat berfungsi sebagai anti agregasi, secara teori kuersetin berfungsi sebagai anti agregasi dengan mekanisme kerja kuersetin yang melakukan penghambatan thrombin sebagai pusat dari pembekuan darah, mengurangi aktivitas thrombin mengkatalisis perubahan fibrinogen menjdi fibrin. Flavonoid kuersetin mampu menstimulasi tissue plasminogen activator (t-PA) yang dihambat thrombin sehingga pembekuan dihambat.

Kesimpulan hasil penelitian sebagai berikut: (1) Konsentrasi mininmal Kuersetin yang masih dapat menjaga kestabilan bahan kontrol buatan adalah $13 \mathrm{mg} / \mathrm{L}$ penyimpanan eritrosit selama 20 hari dan $13 \mathrm{mg} / \mathrm{L}$ penyimpanan lekosit selama 15 hari. (2) Homogenitas bahan kontrol buatan dengan penambahan kuersetin untuk pemeriksaan hematologi adalah homogen untuk eritrosit dan lekosit. (3) Stabilitas bahan kontrol buatan dengan penambahan kuersetin untuk pemeriksaan hematologi pada penyimpanan 2$8^{\circ} \mathrm{C}$ adalah stabil selama 20 hari untuk pemeriksaan eritrosit, stabil selama 15 hari untuk pemeriksaan lekosit dan tidak stabil untuk pemeriksaan trombosit menggunakan konsentrasi kuersetin minimal $13 \mathrm{mg} / \mathrm{L}$. (4) Kinerja bahan kontrol buatan dengan penambahan kuersetin dibandingkan dengan bahan kontrol komersial adalah pada pemeriksaan eritrosit hasil lebih baik.

Saran untuk dilakukan penelitian lebih lanjut untuk mengetahui konsentrasi optimum kuersetin yang dapat menstabilkan bahan kontrol darah buatan. Perlu juga ditentukan konsentrasi kuersetin yang dapat berfungsi sebagai antiagregasi trombosit pada bahan kontrol buatan.

\section{Daftar Pustaka}

Dean, L. 2005. Blood Groups and Red Cell Antigents, National Center for Biotechnology Information (US), Bethesda (MD).

Peraturan Menteri Kesehatan Republik Indonesia Nomor 43 Tahun 2013 Tentang Cara Penyelenggaraan Laboratorium Klinik Yang Baik.

PMK RI Nomor 37 tahun 2012 tentang Penyelenggaraan Laboratorium Puskesmas. 
Sacher, RA., Mc Pherson, RA. 2004. Tinjauan Klinis Hasil Pemeriksaan Laboratorium. Jakarta: Buku Kedokteran EGC

Tuna H., Widyaningsih A. 2017. Perbandingan antara Bahan Kontrol Komersial Merk Diasys-Trulab N dengan Siemens-Biorad Level 1 terhadap Akurasi untuk Pemeriksaan Glukosa, Kolesterol dan Asam Urat. Jurnal Wiyata: Penelitian Sains dan Kesehatan 3(1), 85.91.

KAN. 2004. Pedoman Statistik untuk Uji Profisiensi. Jakarta.

Tuntun, M, Wulan WS, Setiawan D, dan Nuryati A. 2018. Bahan Ajar Teknologi Laboratorium Medik (TLM): Kendali Mutu. Jakarta: Pusat Pendidikan Sumber Daya Manusia Kesehatan.

Dewi RS, Sandhiutami NMD, Raharjo S. 2017. Efek Anti-Agregasi Platelet Ekstrak Etanol Daun Salam (Syzygium polyanthum (Wight) Walp.) pada Mencit. Jakarta: Fakultas Farmasi Universitas Pancasila. 